\title{
The Role of The Perlis State Mufti Department in Restraining Covid-19 Through Fatwas and Legal Guidelines
}

\author{
Fathullah Asni, Ahmad Yusairi Yusli \& Amirah Izzati Umar
}

To Link this Article: http://dx.doi.org/10.6007/IJARBSS/v11-i10/11298

DOI:10.6007/IJARBSS/v11-i10/11298

Received: 12 August 2021, Revised: 01 September 2021, Accepted: 22 September 2021

Published Online: 08 October 2021

In-Text Citation: (Asni et al., 2021)

To Cite this Article: Asni, F., Yusli, A. Y., \& Umar, A. I. (2021). The Role of The Perlis State Mufti Department in Restraining Covid-19 Through Fatwas and Legal Guidelines. International Journal of Academic Research in Business and Social Sciences, 11(10), 311-328.

\section{Copyright: (c) 2021 The Author(s)}

Published by Human Resource Management Academic Research Society (www.hrmars.com)

This article is published under the Creative Commons Attribution (CC BY 4.0) license. Anyone may reproduce, distribute, translate and create derivative works of this article (for both commercial and non-commercial purposes), subject to full attribution to the original publication and authors. The full terms of this license may be seen at: http://creativecommons.org/licences/by/4.0/legalcode

\section{Vol. 11, No. 10, 2021, Pg. 311 - 328}

Full Terms \& Conditions of access and use can be found at http://hrmars.com/index.php/pages/detail/publication-ethics 


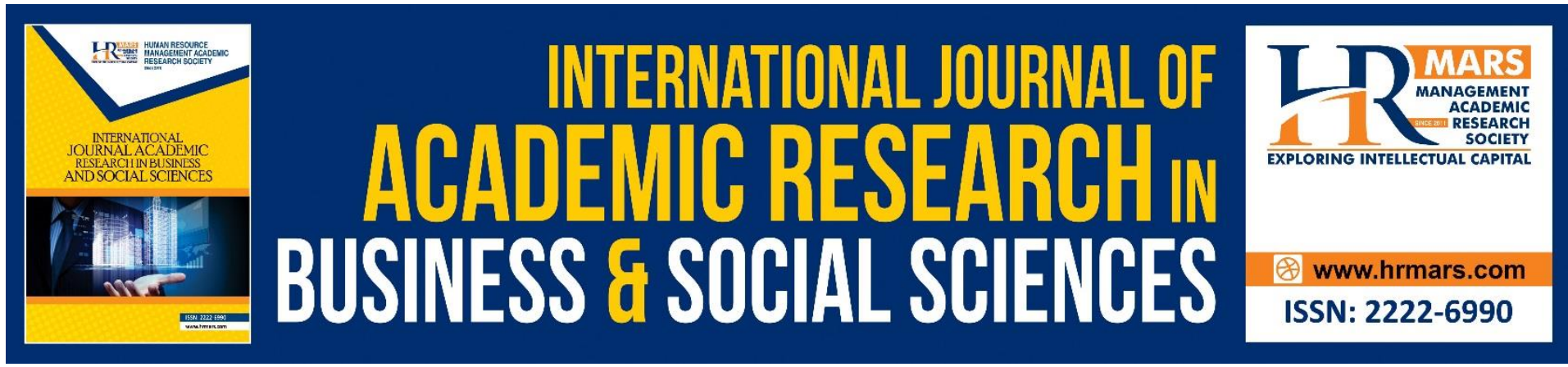

\title{
The Role of The Perlis State Mufti Department in Restraining Covid-19 Through Fatwas and Legal Guidelines
}

\author{
Fathullah Asni ${ }^{1}$, Ahmad Yusairi Yusli² \& Amirah Izzati Umar ${ }^{3}$ \\ Shariah Department, Faculty of Islamic Studies, Kolej Universiti Islam Perlis (KUIPs) \\ Email: ${ }^{1}$ fathullah@kuips.edu.my, ${ }^{2}$ ahmad_yusairi@kuips.edu.my, \\ 3amirahizzati@kuips.edu.my
}

\begin{abstract}
The spread of COVID-19 has had a detrimental effect on various sectors, especially on the health sector, where it has resulted in hundreds of thousands of deaths being recorded worldwide. The spread of this epidemic has led the World Health Organization (WHO) to declare COVID-19 a pandemic. Specifically, in Malaysia, the number of infected individuals is 1.8 million cases, and the number of deaths is 17,000 cases. Various parties comprising the Federal Government and the authorities have taken various approaches to curb the spread of the COVID-19 epidemic from continuing spread. Meanwhile, in the state of Perlis, among the bodies responsible for curbing the spread of this epidemic is the Perlis State Mufti Department which is responsible for issuing fatwas for Islamic religious affairs to be followed by Muslims, especially in the state of Perlis. Based on this background, this study would like to examine the role of fatwas issued by the Perlis Mufti Department in curbing the spread of COVID-19. This study uses a qualitative approach involving a literature review covering books, journals, fatwas and related circulars. The data obtained will be analyzed using document analysis methods. The study results show that there are four official fatwas and four legal guidelines issued related to COVID-19. The study results found that all fatwas and legal guidelines issued were aimed at curbing the spread of the COVID-19 epidemic and based on strong Islamic arguments. The study ended with some suggestions for improvement after a discussion was done on the study results.
\end{abstract}

Keywords: Fatwa, Perlis State Mufti Department, Covid-19, Outbreak, Pandemic

\section{Introduction}

From the end of 2019 until now, every country faces major challenges when attacked with the COVID-19 virus. The virus not only carries disease, but it can also be life-threatening. The spread of the virus outbreak prompted the World Health Organization (WHO) (2020) to categorize the condition as a pandemic. This is because the epidemic is so widespread without borders that it threatens areas worldwide and is difficult to control. The spread of this epidemic has adversely affected the whole world, including Malaysia. The outbreak resulted in more than 4.5 million deaths, and more than 220 million people were infected with COVID- 
19 worldwide (Worldmeters, 2021). Thus, among the things most affected due to the spread of this epidemic is the health sector.

The pandemic that has hit the whole world has caused Malaysia to be plagued by instability, including economic, social, job loss, lack of resources, health problems, and many more (Utusan, 2020). When health experts confirmed that COVID-19 disease could be spread through human transmission agents, namely through coughing that produces droplets of fluid or speech that can cause splashes of saliva, it has led the government to take various initiatives to stop the spread of the virus as directed people work from home, do not leave the house unless there is important business, physical distance, cannot gather involving many people, restrict entry in a closed place, cannot cross districts or states and many more (Bharian, 2020).

Furthermore, the world is now shocked by the COVID-19 mutation variant known as Delta, Beta and Alpha, where it can infect in a very fast period within 15 seconds with a distance of one meter and can spread through the air (Bharian, 2021). This causes the infection and the effects of the virus on the human body to increase. This can be seen in the record of infections and deaths between 2020 and 2021 is multiplied. To date, in Malaysia, it is recorded that there are almost two million people infected, and it has resulted in more than 17 thousand deaths due to COVID-19 infection (COVID-19/Ministry of Health Malaysia, 2021).

The bad pandemic has indirectly affected the religious activities of Muslims in Malaysia. This is because Islam is very important to do its activities in the congregation, such as gathering in the mosque to perform various types of worship such as prayer, breaking fast, seeking knowledge and many more. Similarly, the majority Muslim community in Malaysia is always involved in religious activities daily. Thus, considering the potentially fatal factor of COVID-19 infection, the usual religious activities required a new approach following the adverse situation that struck (Ismail, 2020).

The current situation requires a new approach involving religious matters to curb the spread of epidemics that can be life-threatening. Thus, this necessitates the role of fatwa as it is a solution to new issues related to Islam (Aji et al., 2020). In the context of the state of Perlis, fatwa matters are under the responsibility of the Perlis State Mufti Department, where the Tuanku Raja of Perlis entrusts the department through the State Islamic Religious Council. Thus, the Perlis State Mufti Department will answer all new issues related to Islam that are in question in the state of Perlis (Yusli et al., 2021; Asni \& Sulong, 2017).

The pandemic threat that occurred outside and inside the country has caused the Perlis State Mufti Department to proactively curb the spread of the epidemic by issuing several fatwas on religious issues during the outbreak of COVID-19. Thus, the objective of this study is to examine the role of fatwas by the Perlis State Mufti Department in curbing the spread of COVID-19.

\section{Literature Review}

\section{Fatwa as a solution to a new problem}

Most of the new problems related to Islam that arise among Muslims in a certain place or time, where the past scholars do not discuss it, then it will be submitted to the mufti (Asni \& Sulong, 2017). Thus, the mufti will conduct legal research to provide answers to the issues raised. Since the early generations of Islam, this concept has been going on (Asni \& Sulong, 2021).

One of the methods to issue a fatwa is through the science of usul fiqh. Usul figh is the main essence in the method of a fatwa, which is the main pre-for the qualification of a mufti. 
A fatwa is a view or decision, either personal or produced by a group of mujtahids, on a particular Shariah law (Asni, 2020). The accuracy of a fatwa is highly dependent on the method of argumentation used and its parallel conformance with maqasid al-shariah (Asni, 2018; Ishak \& Asni, 2020). According to al-Ghazali (1997), a mufti is a mujtahid who can perform ijtihad and infer the law. Thus, a mufti and a mujtahid are the same in general, as the difference in both terms only refers to the cause, whereby a fatwa is issued to answer a question or a problem that has occurred while ijtihad is not bound by such conditions (alAshqar, 2008).

However, a mufti can proactively address a question by directing legal research even if there is no application for a fatwa as a preparatory measure (Khudzri, 2006). Thus, some scholars do not differentiate between the functions of a mufti and a mujtahid because each individual can issue a fatwa, regardless of whether there is an existence of questions or not (al-Shatibi, 1997).

Al-Shaukani (1999) defined ijtihad as mobilizing the ability to obtain a comprehensive Shariah law by following the method of istinbat. While al-Amidi (2003) defined ijtihad as pouring all the ability to understand the Shariah law which is zanni (uncertain), when he feels unable to find more than that. Thus, ijtihad can be understood as the effort of a mujtahid who maximizes all his mental and intellectual efforts to study and understand the Shariah law. The effort ultimately produces findings or results from such ijtihad, which is called a fatwa (Asni \& Sulong, 2017). Thus, based on the concept of fatwa discussed, it is a solution to new issues related to Islam, where there is no evidence to be referred directly either from the Qur'an and hadith to solve the new problems (Asni et al., 2016).

\section{Fatwa Change Factors}

Islam is a complete religion, where all the rules have been determined in all aspects of human life, covering the question of faith, worship, morality to the affairs of society and nationhood, which includes economic, educational, political and social domains at all times and places. The sources of law from the Qur'an and hadith are the best guide to human beings where it is the revelation of Allah SWT, which explains the law for every question in daily life (Sanu, 2000).

Every law found in the Qur'an and hadith includes two components, namely althawabit (which is fixed and permanent) and al-mutaghayyirat (which can change). AlThawabit is the fundamentals of Islam which are the pillars, foundations and principles of the religion that do not change until the Day of Judgment, while al-mutaghayyirat are the branches (furu') law that can change according to the circumstances and times (al-Qaradawi, 2002). Laws that can change are subject to current reality (waqi'), which usually refers to the current values of culture, customs or 'urf, and the needs of a community in a locality. These changes aim to safeguard the welfare of human life following the purpose for which the Shari'ah was revealed. The component of al-mutaghayyirat consists of laws that are ijtihads in various fields of figh and it can be further developed by Islamic scholars. In other words, Islamic law is fixed on matters of usul and flexible (murunah) on matters of branches that involve many current questions in any dimension of human life (al-Qaradawi, 2000).

Today's world is also witnessing more advanced technology. More new things are emerging involving legal problems that never arose during the time of past scholars. No legal answer to these problems is found in the treasures of the works of past scholars (al-Qaradawi, 2005). Most of the current problems that are branches (furu') are not found in detail in the Qur'an and Sunnah. Typically, most of such problems are included in the mutaghaiyyirat 
component. However, the general principle in the form of fundamental or thawabit has been enshrined in both sources and has always been a binding policy guide in determining the law for the matter of furu' (al-Qaradawi, 2008).

In the history of the development of Islamic law, various fiqh laws were born because of the process of ijtihad by a scholar based on factors during his time. It is evident in the era of the Companions, the Tabi'in and the Tabi' al-Tabi'in, the time after that to the present era. For example, Caliph Umar al-Khattab did not impose hudud punishment on thieves due to economic factors during the emergency, while Caliph Uthman added a second azan on Friday in the Madinah market due to social factors (al-Zuhaili, 2000). Some Tabi'in founded the madrasah al-ra'yi based on the fiqh of the urban community in Baghdad.

The scholars in an era or place have opinions different from what was decided by the scholars after them or elsewhere (Asni, 2017). In fact, there are scholars in a school who do not follow the views of the imam of his school as Imam Abu Yusuf and al-Shaibani who put forward many different views with Abu Hanifah even though they are loyal disciples of Abu Hanifah (Abu Sulayman, 2006). The same pattern is also clearly seen in other sects. This is because, even though they are loyal followers of the imams of the sect, their ijtihad needs to be changed to suit the changing realities of society. The same example is also by al-Shafi'i who has qawl qadim (old opinion) and qawl jadid (new opinion) in his fiqh which is based on the factors of difference that occurred in Hijaz and Egypt (al-Hajawi, 1995). Therefore, the scholars of usul fiqh formulated a method of fiqh which means, "there is no denying the change of law with the change of time (al-Nadwi, 1998)."

There are also laws decided in the past that are no longer practical to apply in the present. This is because social change factors that are different from the past and the interpretation of a case can also change with changes in current reality (al-Hajawi, 1995). Therefore, Islam provides a solution to these problems by opening space for scholars to perform ijtihad to answer new legal problems. On the premise of legal thinking is the construction of the current concept of figh mentioned in the terminology of al-fiqh al-mu'asir or fiqh of reality (al-fiqh al-waqi'i) (Al-Qaradawi, 2000).

The terminology of current fiqh or fiqh al-waqi' refers to the understanding of Islamic law in the current context, especially the laws on new issues that require new ijtihad and has never been mentioned in any Shariah source or past opinions of the scholars. Al-Qaradawi (2008) defined fiqh al-waqi' as understanding reality well and not knowing it by mere shadow simply because it is a falsehood and misguidance.

Thus, it can be concluded that current fiqh refers to figh based on reality centred on the consideration between maslahah and mudarat. It is not something in the form of fantasy or expectation (iftiradi). Therefore, a scholar of fiqh in the process of issuing his ijtihad on an issue must understand and live with the existing reality and focus his ijtihad on the consideration between maslahah and mudarat, guided by Shariah sources and put it under current reality (Bukhari, et al., 2020).

\section{Fatwa Methodology of Perlis State Mufti Department}

The methodology of fatwa determination in the state of Perlis has been determined based on the two provisions, namely (Dahlan et al., 2014):

i. The Perlis Government Constitution Act 1948 states, "The Religion of the State shall be the Muslim Religion Ahli Sunnah Waljama'ah as heretofore professed and practised in the State." 
ii. The Perlis Islamic Religious Administration Law 1964 states, "When the Majlis issued a fatwa and the Shariah Committee gives its opinion, then the body must follow the Quran and the Sunnah of the Prophet PBUH."

Both provisions do not explain in detail the policies that need to be taken in deciding a fatwa. Therefore, the Perlis State Shariah Committee decided the meaning of Ahl al-Sunnah wa al-Jama'ah, while at the same time, explained the fatwa methodology that refers to the Quran and Sunnah. JSNP in 1970, with the consent of MAIPs, has issued a fatwa regarding $A h l$ al-Sunnah wa al-Jama'ah and the policies in taking legal sources for a fatwa issued and the holding position the schools of fiqh (Dahlan et al., 2014).

The first thing that was improved concerns the fatwa reference source. Based on the decision of the Fatwa on Ahl al-Sunnah wa al-Jama'ah issued by MAIPs through JSNP, to issue a fatwa, the Shariah Committee must be guided by its fatwa based on the following principles according to priority, al-Quran, hadith, ijma', fatwa of companions closer to the Quran and Sunnah, hadith mursal and daif, qiyas, masalih mursalah, sad al-dharai', istihsan, istishab, 'uruf, qawa'id fiqhiyyah (Dahlan et al., 2014).

While the second thing that was improved is the methodology of determining the fatwa as the attachment of the fatwa with a particular sect. Thus, the JSNP has ruled that the authoritative fatwa body is not bound by any particular sect. This means that the committee needs to consider all recognized sects such as Hanafi, Maliki, Shafi'i and Hanbali, to prescribe a fatwa with strong backing from the Quran and Sunnah (Dahlan et al., 2014).

The Perlis fatwa reference approach implies that the decision of a fatwa must look at the changing public interest according to the current situation and the core reference to Shariah propositions (Asni \& Sulong, 2017; Asni et al., 2017). When this relationship is built, then an accurate fatwa (rajih) decision will be achieved. Based on the study of Omar and Hussin (2018), although fatwa references made by mufti departments are more inclined to sectarian references, mufti departments also refer to fiqh methods as supporting in strengthening fatwas.

\section{Methodology}

The methodology of this study is qualitative, where the data is obtained through a literature review by referring to books, journals, official websites, and related circulars. The researchers first highlighted the study related to the concept of fatwa as a solution to new problems, fatwa change factors and fatwa methodology of the Perlis state mufti department. Because the mufti's department publishes fatwas and laws on its official website, it is easy for the researchers to obtain information regarding fatwas and laws issued.

Then the researchers screened the list of fatwas and legal guidelines issued by the Perlis State Mufti Department from the end of 2019, during the beginning of the COVID-19 epidemic that hit Malaysia. As a result of the screening, the researchers found four fatwas and four legal guidelines issued related to COVID-19. The researchers consider the official fatwas and legal guidelines issued because both categories are legal guidelines to the Muslim community. Then the researchers conducted a content analysis of the data obtained to meet the study's objectives, namely the role of the fatwa issued by the Perlis Mufti Department in curbing the spread of COVID-19.

\section{Result and Discussion}

Based on the screening results of the list of fatwas and legal guidelines issued by the Perlis State Mufti Department from the end of 2019, during the beginning of the COVID-19 epidemic 
in Malaysia, it was found that there are four official fatwas and four legal guidelines related to efforts to curb COVID-19.

Table 1: Fatwas \& Legal Guidelines related to COVID-19

\begin{tabular}{|c|l|c|}
\hline No & \multicolumn{1}{|c|}{ Fatwas \& Legal Guidelines } & Status \\
\hline 1 & Fatwa on taking of COVID-19 vaccine & Official fatwa \\
\hline 2 & Fatwa on vaccination for individuals who are fasting & Official fatwa \\
\hline 3 & Fatwa left Friday prayer due to duty & Official fatwa \\
\hline 4 & $\begin{array}{l}\text { Fatwa on marriage contract through live video } \\
\text { conference }\end{array}$ & Legal guide \\
\hline 5 & $\begin{array}{l}\text { The law on swab test for COVID-19 screening for fasting } \\
\text { persons }\end{array}$ & Legal guide \\
\hline 6 & $\begin{array}{l}\text { Guidelines on procedures for the management of } \\
\text { Muslims remains COVID-19 }\end{array}$ & Legal guide \\
\hline 7 & $\begin{array}{l}\text { The law does not want to take the COVID-19 vaccine } \\
\text { The law for merging prayers for Malaysian Health }\end{array}$ & Legal guide \\
\hline
\end{tabular}

1. Fatwa on taking of COVID-19 vaccine.

Based on the decision of the 51st Perlis State Fatwa Committee/2021 meeting on the law of taking COVID-19 vaccine held on 22 February 2021, the Fatwa Committee decided, "The use of COVID-19 vaccine is allowed, and it must be taken by those designated by the Government Malaysia (Perlis State Mufti Department, 2021)."

Based on the fatwa, the Perlis State Mufti Department has stated the mandatory law on vaccination by most of the community in Malaysia. This is because the federal government stipulates that $80 \%$ of the entire Malaysian population must take the vaccine to create cluster immunity (COVID-19/Ministry of Health Malaysia, 2021). The decision of this fatwa is very helpful to curb the spread of COVID-19. This is because taking the vaccine can prevent being infected with the virus.

When a large portion of a community's population is protected from infection, the virus is difficult to infect. Thus, the whole society will be protected from the infection of the disease which is termed as 'cluster immunity' where it is only achieved with high immunization coverage (COVID-19/Ministry of Health Malaysia, 2021). It can protect those who do not have immunization protection and are at risk of being infected with the virus. Thus, immunization not only protects individuals but also protects all walks of life. As members of society, it is our responsibility to protect those who are not eligible to receive immunizations such as children with cancer and need to undergo chemotherapy because they are at risk of getting an infection (COVID-19/Ministry of Health Malaysia, 2021).

In terms of risk, clinical trials are conducted to determine the safety and effectiveness of the vaccines developed. If there are severe adverse effects, then the vaccine will not be approved. Therefore, vaccines that have passed phase 3 clinical trials, and are approved by the National Pharmaceutical Regulatory Agency (NPRA), are safe to take and effective in protecting against COVID-19 disease (COVID-19/Ministry of Health Malaysia, 2021).

The Perlis State Mufti Department is not alone in deciding on the mandatory law on vaccination, in fact the Muzakarah National Fatwa Committee also issued the same decision, Universiti al-Azhar al-Syarif Egypt, Fatwa Council of the United Arab Emirates (UAE), Majma' 
Fuqaha' al-Shari'ah America (Minister in the Prime Minister's Department of Religious Affairs, 2020).

In addition, the fatwa issued is based on the methods of fiqh that are, "there is no harm and there is no act of retaliation," as well as the method that means, "a general desire is equivalent to a specific emergency position (al-Zarqa', 2012)." In addition, the mandatory instructions are in line with the religious instructions to follow the government's instructions (al-Zuhaili, 2013). This is because if the government gives instructions that bring the interests of the public, then it is obligatory to be followed by the people as in the words of Allah SWT which means, "O you who believe, obey Allah and obey the Messenger and (obey you) to the ulil amri from among you (al-Nisa': 59)."

2. Fatwa on vaccination for individuals who are fasting.

Based on the decision of the 52nd Perlis State Fatwa Committee/2021 meeting on the law of vaccine injection for a fasting person held on 19 - 20 March 2021, the Fatwa Committee decided, "Medical injections that do not pass-through open body cavities and not as a substitute for food and drink including vaccine injections do not invalidate the fast (Perlis State Mufti Department, 2021)."

This decided fatwa states that injections that do not pass through an open body cavity and are not substitutes for food and drink do not invalidate the fast. This fatwa is a new issue not discussed in classical figh. Thus, it is discussed by current scholars about the law of taking vaccine injections while fasting whether it invalidates the fast or not. Thus, looking at the discussions of current scholars, this fatwa is in line with the opinions of (Ibn Bazz, 1999; Ibn 'Uthaimin, 1999; al-Qaradawi, 1997).

Similarly, it aligns with the popular fatwa body, namely Majma' Fiqh Islami (2021). The injection does not invalidate the fast because the vaccine injection performed today is not through an open body cavity, and the vaccine is not in the form of food or drink that can satisfy. Thus, it is not included in matters that invalidate the fast as discussed by the recognized scholars. The decision of this fatwa is very helpful in curbing the spread of COVID19. This is because, it can avoid the confusion of society to take the vaccine even while fasting. This can help the government achieve group immunity more quickly, involving $80 \%$ of the Malaysian population to take vaccinations (COVID-19/Ministry of Health Malaysia, 2021).

3. Fatwa left Friday prayer due to duty.

Based on the decision of the 50th Perlis State Fatwa Committee meeting/2020 on the law of abandoning Friday prayer due to duty held on 14 December 2020, the Fatwa Committee decided, "Friday prayer must be performed by every Muslim who meets the obligatory conditions of Friday prayer. Thus, a Muslim cannot leave Friday prayer without the obstacles allowed by Shariah. Included in the barriers to leaving Friday prayer are critical duties such as security guards, health workers, traffic officers, military personnel, police, firefighters, and rescuers, and the like who have to work during Friday prayer and no other substitutes are not required to perform Friday prayer such as non-Muslims, women or people who travel (musafir). A person who does not perform Friday prayer due to obstacles must replace it with Zohor prayer (Perlis State Mufti Department, 2021)."

This fatwa states that critical officers may abandon Friday prayer and replace it with Zohor prayer. This fatwa is in line with the opinion put forward by al-Suyuti (1998) that among the examples of barriers that can leave Friday prayer are the caregivers of the sick. This view is also supported by (al-Nawawi, 2000; Ibn 'Abidin, 2001; al-Mardawi, 1956; Lajnah Daimah Saudi, 1996). 
In the opinion of the researchers, this fatwa is very helpful in dealing with the pandemic situation currently. This is because, with the number of COVID-19 infections being more than 20,000 cases a day, it requires a high level of commitment from the nation's frontliners comprising medical officers, nurses, enforcement officers and anyone involved in dealing with COVID-19 (COVID-19/Ministry of Health Malaysia, 2021). Therefore, the frontline officers of the country should be given flexibility based on the fatwa issued to replace Friday prayer with Zohor prayer. This will cause hospitals, quarantine places, roadblocks between districts and states and the places involved to be managed optimally. This flexibility is also allowed by Shariah as it involves an interest in life care.

4. Fatwa on marriage contract through live video conference.

Based on the decision of the 46th Perlis State Fatwa Committee (2021)/2020 meeting on the fatwa of marriage contract through live video conference held on 17 June 2020, the Fatwa Committee decided, "marriage contract through live video conference is permitted by Shariah, if it is believed by the parties involved to have fulfilled the tenets of marriage and its conditions and free from any fraud."

Based on the fatwa decided, the committee agreed that the marriage contract through live video conference is permissible. This fatwa is very important to curb the spread of the COVID-19 epidemic. This is because the wedding ceremony organized by Shariah requires the gathering of several people, namely the prospective husband and wife, the families of the two brides, the registrar's representative and the public in one place. However, such activities should not be carried out during this epidemic period as it can be lifethreatening due to COVID-19 transmission when a group of individuals are in close contact.

Thus, an alternative method to prevent the spread of the epidemic is to conduct a wedding ceremony through virtual video conferencing which does not require the parties involved to gather in one place physically but meet virtually, and then it can avoid the gathering of several individuals in one place. The fatwa is in line with the fatwa issued by (AlIslami, 1990; Muzakarah National Fatwa Committee, 2013; Selangor State Mufti Department, 2016).

5. The law on swab test for COVID-19 screening on fasting persons.

Regarding the swab test for COVID-19 screening on a fasting person, the Perlis State Mufti Department decided that it did not invalidate the fast. This law was published on 5 June 2020 on the official website of the Perlis State Mufti Department and did not state the results of the Fatwa Committee meeting (Perlis State Mufti Department, 2021).

The law was issued following the COVID-19 management guidelines implemented by the Ministry of Health Malaysia ( $\mathrm{MOH})$. The screening method in determining COVID-19 positive individuals is through nasopharyngeal swab and oropharyngeal swab. The nasopharyngeal swab method is a swabbing device inserted into the individual nasal cavity up to the nasopharynx area with a depth of approximately $4.8 \mathrm{~cm}$ for children and $8-12 \mathrm{~cm}$ for adults. It aims to take a mucus sample. While the oropharyngeal swab method is a swabbing device inserted into the mouth to the oropharynx area at the back of the child's throat to take a mucus sample. The insertion of a swabbing device into the oral and nasal cavity raises the question of whether fasting status becomes void or otherwise (Perlis State Mufti Department, 2021).

Based on the problem, the mufti department decided that the swab test for COVID19 screening was not to invalidate the fast due to the following arguments (Perlis State Mufti Department, 2021); 
I. According to the consensus of scholars, the swab test does not bring a meaning of eating or drinking, which is the reason for cancelling the fast. Thus, the practice of confidently valid fasting cannot be considered void by something suspicious or merely an assumption.

II. Making the excuse of inserting something into the al-jauf (internal cavity of the body) as a reason to cancel the fast causes differences of opinion among the scholars of the sect. The chosen view that the swab test does not invalidate the fast coincides with the view of some Hanafi scholars who require that something that enters al-jauf must be something that remains in it and not connected to something else outside the body.

III. It is supported by the opinion of al-Majma' al-Fiqhi al-Islami who has listed several medical issues that do not invalidate fasting including inserting a gastroscope (stomach binoculars) into the stomach without any fluid or the like. Therefore, it is more important for a swab test that only involves the process of inserting a swabbing device into the nasal cavity or mouth to obtain the required sample, then re-removed is not to invalidate the fast.

The fatwa decided is in line with the fatwa decided by the Malaysian Islamic Religious Affairs Council (MKI), the Federal Territory Mufti Department (2021) and the Indonesian Ulema Council (CNN Indonesia, 2021). The decision of this fatwa is very helpful in curbing the spread of COVID-19. This is because, it can avoid the community's confusion to make a swab test even while fasting. The COVID-19 screening test is very important because it is an effective tool to detect COVID-19 infection and preventive action, which can be done from the results of screening tests made.

6. Guidelines on procedures for the management of Muslims remains COVID-19.

Regarding the guidelines on procedures for managing the remains of Muslims infected with the COVID-19, the Mufti Department submitted guidelines that include legal guidelines, procedures for managing the remains and burial of the remains. These guidelines were published on 13 April 2020 on the official website of the Perlis State Mufti Department and did not state the results of the Fatwa Committee meeting (Perlis State Mufti Department, 2021).

Based on the guidelines, the researchers found that several elements can curb the spread of epidemics in the management of the remains, namely (Perlis State Mufti Department, 2021);

a. The Perlis State Fatwa Committee follows the policy set by the Ministry of Health Malaysia in handling the management of corpses that died because of COVID-19.

b. Bathing and shrouding should be arranged at a hospital or any premises authorized by the authorities.

c. It is allowed to take rukhsah (Islamic relief) by performing tayammum directly on the face and wrists of the corpse to replace the corpse bath with water.

d. Suppose it is harmful and tayammum can't be performed on the corpse directly. In that case, the tayammum process is not obligatory on the corpse, including on the plastic or body bag that wraps the corpse. This approach was taken because of the autopsy findings on the corpses of COVID-19 patients, found the presence of a virus on the surface of the corpse through Real-time Polymerase Chain Reaction (RT-PCR) analysis conducted by the Institute for Medical Research (IMR).

e. Officers must be fully dressed in safety following the procedures prescribed by the $\mathrm{MOH}$ when handling the management of COVID-19 remains. 
f. Funeral prayers must be performed by the hospital staff involved only to fulfill the demands of fardh kifayah.

g. The funeral process is managed by hospital staff or special staff who are designated and have been trained by the procedures as prescribed by the $\mathrm{MOH}$.

h. All officers involved are required to clean themselves according to the procedures set by the $\mathrm{MOH}$.

Based on the guidelines issued, it is a comprehensive guide in curbing the transmission of COVID-19 especially to the staff in managing infected corpses. Apart from that, it was found that the mufti department took the rukhsah method by performing tayammum on the corpse to replace the bath or not performing tayammum if the situation did not allow it.

Although the approach is very good to curb the spread of the epidemic, the two approaches can confuse the staff that is the situation where to perform tayammum and the situation where it is not necessary to perform tayammum. Therefore, it is proposed to the Mufti Department to organize one of the methods not to confuse the staff. According to the researchers, not doing tayammum is better because there is a risk of physically bathing the corpse and tayammum according to the $\mathrm{MOH}$. Thus, it can avoid danger to the lives of the staff as advocated by Islam. This proposal is in line with the fatwa issued by the (Selangor State Mufti Department, 2021).

7. The law does not want to take the COVID-19 vaccine.

Regarding the law for individuals who do not want to take the COVID-19 vaccine, it was issued in the form of the 6th Irsyad Hukum series by the (Perlis State Mufti Department, 2021). After reading the entire article that has been published, the researchers found that the mufti department opined that Muslims who are able to do not want to take the vaccine deliberately is an offence and can bring a person to sin for having violated the order of ulul amri (government).

The Mufti Department has also come up with various strong arguments covering the Quran and the hadith of the Prophet PBUH. This fatwa is in line with fatwas issued by local and international scholars as well as local and international fatwa bodies consisting of the Perak State Mufti (Berita Harian, 2016), Kelantan State Mufti (Berita Harian, 2016), State Mufti Terengganu (Bernama, 2016; Federal Territory Mufti Department, 2021; Dar al-Ifta' Egypt, 2003; Union of African Muslim Scholars, 2006; Al-Islami, 2013; al-Qaradawi, 2010).

The publication of the law is very appropriate because the media often report that many communities still reject the COVID-19 vaccine injection for various reasons. Among those who reported rejecting the vaccine were anti-vaccine groups, teachers, indigenous people and the general public, as reported by (Astro Awani, 2019; Harian, 2020; Harian, 2021). This problem will make it difficult for the government to create group immunity to curb the spread of the epidemic because it does not reach $80 \%$ of Malaysians involved with vaccination. However, the researchers would like to suggest that this legal guide be adopted as an official fatwa, so that the public is more confident in the status of the law issued. Sometimes, the public does not take the law seriously if it is not adopted as an official fatwa.

8. The law for merging prayers for Malaysian Health Ministry staff involved in treating COVID-19 patients.

Regarding the law of merging prayers for staff involved in treating COVID-19 patients, it was issued in the form of Irsyad Hukum series three by the (Perlis State Mufti Department, 2020). The Perlis State Fatwa Committee is opined that hospital staff who are directly involved in treating COVID-19 cases in hospitals are allowed to perform jama' prayers without qasar with the following guidelines: 
1. Originally, it was obligatory to perform prayers on time as long as possible, and it was forbidden to merge (jama') prayers without urgent needs or travellers.

2. If the situation is urgent and a person can skip the Zohor or Maghrib prayers until the end of the time and the Asar and Isyak prayers at the beginning of the time, it is more important. This is called jama' suri (merge in the picture only) according to Mazhab Shafie.

3. If not able to perform jama' suri, it is permissible to perform the jama' prayers either the jama' taqdim or ta'khir depending on the suitability of the staff on duty.

4. Jama' prayers are performed out of desperation and difficulties that have already occurred or are expected to occur with strong belief, not because of ease in religion or conjecture without evidence.

The fatwa committee submitted arguments from the hadith to support the above opinion, which is the hadith narrated by Ibn Abbas which means, "The Prophet PBUH used to jama" Zohor and Asar prayers in Madinah without any fear and travel." When asked why he did so, Ibn Abbas RA replied, "He did not want to bother anyone from his ummah (Muslim, 2006)."

According to al-Zuhaili (1985), the Hanbali school clearly places a state of sickness and busyness as a condition that allows jama' prayers. Among the examples of those who fall into this group are worried about themselves, their honour, or their property which leads to misfortune or can endanger their employment when leaving jama' prayers. This section is dedicated to workers, officers, farmers.

Looking at the current pandemic situation, there is no denying that Malaysia is a critical country in dealing with COVID-19. In addition to the shortage of staff consisting of doctors and nurses, the country is facing an increase in the number of patients infected with COVID-19 reaching tens of thousands in a day. Therefore, the legal issue by the Perlis Fatwa Committee is very relevant.

Basically, the need to jama' prayers for the Ministry of Health Malaysia staff is seen as practical with the situation of those who need to wear PPE Personal Protective Equipment (PPE) while on duty without being able to open it during duty hours. Similarly, most health workers have no choice in determining their shift times. Therefore, looking at the situation of having to carry out tasks for a long period to make it possible to miss the prayer time, they can choose the time to assemble the prayers that suit their situation.

Thus, the researchers suggested that if the shift time of the health worker starts before the time of the first prayer and ends at the time of the second prayer, then the worker can choose to perform the prayer in jama' ta'khir. However, if the time starts after the time of the first prayer and ends until after the time of the second prayer, then the officer can perform the prayer in jama' taqdim. This is one example of practical relief today that needs to be understood given that the work of health workers is focused on the lives of patients.

This coincides with fiqh's method, which means, "A matter when narrow, will be expanded (Al-Suyuti, 1998)." When a matter becomes difficult, then relief will be given as an area to perform worship (Al-Zuhaili, 1985). Narrow situations for Health staff include situations that are given flexibility such as situations where no other staff can manage patients or are involved in treating critically ill patients who cannot leave the treatment room. However, this flexibility will be lost if the situation is under control and the staff has enough rest time to perform prayers as usual.

Based on the discussion on all fatwas and legal guidelines issued by the Perlis State Mufti Department related to COVID-19, it was found that the entire fatwa aims to curb the 
spread of COVID-19 related to Islamic religious affairs. However, there are some suggestions to be made for improvement as follows;

Putting important issues in the status of official fatwas

The researchers found that there are legal debates only expressed in the form of Irsyad Hukum, whereas it is an important issue to be raised as an official fatwa. This can be seen in the law for individuals who do not want to take the COVID-19 vaccine. At a time when many members of the public are still refusing to take the vaccine as reported by the media, then the law of not wanting to take the vaccine should be lifted as an official fatwa. This is because, when the law is lifted as an official fatwa, then it is more trusted by the public to follow.

Issuing fatwas together with Shariah arguments

When a fatwa committee decides on a fatwa, it is based on a complete research paper and concrete Shariah arguments. However, such arguments are not stated at all with sighah fatwa. This can reduce the public's confidence in the fatwa decision, especially when it involves life and safety issues. Therefore, it is proposed to the mufti department not only to issue a brief sighah fatwa, but together with Shariah arguments based on the fatwa. This is like the fatwas issued by Dar al-Ifta' Egypt, Jordan, Saudi Arabia and others. Thus, it can increase the public's trust in the credibility of a fatwa issued. In addition, today many members of the public are educated.

Based on the study of (Buang \& Che Rosli, 2016; Rosidi et al, 2021), among the factors that can increase public confidence and trust in fatwas, the fatwa institutions should publish fatwa results complete with discussion papers and fatwa references for reading and community reference. Each fatwa issued is accompanied by an explanation and supported by arguments from Islamic legal sources. If the fatwa is explained in a very concise form, its effect can raise doubts among certain parties, especially those who really need clarification on important issues (Nawi, 2014).

Issue more fatwas related to COVID-19 issues

After analyzing the list of fatwas issued by the Perlis State Mufti Department since the end of 2019 when the COVID-19 virus spread to Malaysia, there are only eight fatwas and legal guides published related to COVID-19 issues.

Thus, the researchers suggested that the mufti department be more proactive in publishing more religious issues related to COVID-19 that are hovering among the public, such as the issue of postponing Friday prayers by the public, performing jama'ah prayers at a distance, husband pronouncing talaq ta'liq if the wife takes the vaccine injection without the husband's knowledge, performing prayers while wearing a face mask, the status of prayers left by COVID-19 patients who are put to sleep by health workers, the method of taking ablutions for COVID-19 patients who unable to go to the ablution place such as patients who need breathing aids all the time and other relevant issues.

These issues need to be addressed by the mufti department because it is a question that often hovers among the public. When the mufti department answers such issues, it can avoid the public being confused in the search for answers to refer to inaccurate legal answers and deviating from Shariah from irresponsible parties. This is in line with Mohamad Al-Bakri, former Minister of the Prime Minister's Department (Religious Affairs) stated that many public members refer to religious issues on social media to be stuck with misleading and inaccurate views (Ismaweb, 2021). 


\section{Conclusion}

The spread of COVID-19 has had a detrimental effect on various sectors, especially on the health sector, where it has resulted in hundreds of thousands of deaths being recorded worldwide. The spread of this epidemic has led the World Health Organization (WHO) to declare COVID-19 a pandemic.

Specifically in Malaysia, the number of infected individuals is 1.8 million cases, and the number of deaths is 17,000 cases. Various parties comprising the Federal Government and the authorities have taken various approaches to curb the spread of the COVID-19 epidemic from continuing spread. Meanwhile, in the state of Perlis, among the bodies responsible for curbing the spread of this epidemic is the Perlis State Mufti Department which is responsible for issuing fatwas for Islamic religious affairs to be followed by Muslims, especially in the state of Perlis. Based on this background, this study would like to examine the role of fatwas issued by the Perlis Mufti Department in curbing the spread of COVID-19.

The study results show that there are four official fatwas and four legal guidelines issued related to the issue of COVID-19. The study results found that all fatwas and legal guidelines issued were aimed at curbing the spread of the COVID-19 epidemic and based on strong Islamic arguments. The study ended with some suggestions for improvement after the discussion, namely placing important issues in the status of official fatwas, issuing fatwas along with Islamic arguments and issuing more fatwas related to COVID-19 issues.

\section{References}

Abu Sulayman, I. (2006). Manhaj al-Bahth fi al-Fiqh al-Islami. Makkah: Maktabah al-Rushd.

Aji, A. M., \& Habibaty, D. M. (2020). Fatwa Majelis Ulama Indonesia tentang penyelenggaraan ibadah dalam situasi terjadi wabah covid-19 sebagai langkah antisipatif dan proaktif persebaran virus corona di Indonesia. Jurnal Sosial \& Budaya Syar-i, 7(8): 673-686.

Al-Amidi, S. M. (2003). Muntaha al-Sul fi 'Ilm al-Usul. Beirut: Dar al-Kutub al-'Ilmiyyah

Al-Ashqar, U. (2008). Fauda al-Ifta'. al-Urdun: Dar al-Nafais.

Al-Ghazali, M. M. (1997). al-Mustasfa fi 'llm al-Usul. Beirut: Muassasah al-Risalah

Al-Hajawi, M. (1995). al-Fikr al-Sami fi Tarikh al-Fiqh al-Islami. Beirut: Dar al-Kutub al'Ilmiyyah.

Al-Mardawi, A. S. (1956). al-Insaf. Qaherah: Matba'ah al-Sunnah.

Al-Nawawi, Y. S. (2000). Al-Majmu'. Jiddah: Maktabah al-Irsyad

Al-Qaradawi, Y. (2000). Fatawa Mu'asirah. Beirut: al-Maktab al-Islami.

Al-Qaradawi, Y. (2002). al-ljtihad al-Mu'asir Bayn al-Indibat wa al-Infirat. Qahirah: Dar alTawzi wa al-Nasyr al-Islamiyyah.

Al-Qaradawi, Y. (2005). Madkhal dli Dirasat al-Shari'ah al-Islamiyyah. Qahirah: Maktabah Wahbah.

Al-Qaradawi, Y. (2008). Al-Sunnah Masdaran lil-Ma'rifah wa al-Hadarah. Qahirah: Dar AlShuruq.

Al-Qaradawi, Y. (2010). al-Shariah wa al-Hayah - Fatawa Mubashirah. See: https://www.youtube.com/watch?v=Osia7-ZNkvl\#t=82 (Accessed on 30.8.2021).

Al-Qaradhawi, Y. (1997). Fiqh al-Siyam. Qahirah: Maktabah Wahbah.

Al-Shatibi, I. M. (1997). al-Muwafaqat. Sa'udi: Dar Ibn 'Affan

Al-Shaukani, M. A. (1999). Irshad al-Fuhul ila Tahqiq al-Haq min 'Ilm al-Usul. Beirut: Dar alKitab al-'Arabi

Al-Suyuti, J. A. (1998). al-Ashbah wa al-Naza'ir. Beirut: Dar al-Kutub al-'Ilmiyyah.

Al-Zarqa', A. M. (2012). Sharh Al-Qawaid Al-Fiqhiyyah. Dimashq: Dar al-Qalam. 
Al-Zuhaili, M. M. (2013). al-Qawaid al-Fiqhiyyah wa Tathbiqatuha fi Al-Madhahib Al-Arba'ah. Dimashq: Dar al-Fikr.

Al-Zuhaili, W. (1985). Al-Fiqh al-Islami wa Adillatuhu. Dimashq: Dar al-Fikr.

Al-Zuhaili, W. (2000). Taghayyur al-ljtihad. Dimashq: Dar Al-Maktabi.

Asni, F. (2018). Analysis of the Concept of Fatwa Uniformity according Mura'ah Al-Khilaf Method. International Journal of Academic Research in Business and Social Sciences, 8(7).

Asni, F. (2020). Management of fatwa standardisation on the practice of bay' 'inah contract in Malaysia: an analysis according to usul al-Fiqh and mura'aht al-Khilaf method. Qualitative Research in Financial Markets.

Asni, F. (2021). The difference of Shariah risk potential and Shariah risk in personal financing products based on tawarruq munazzam contracts practised in Malaysia. Qualitative Research in Financial Markets.

Asni, F. A. H. M. (2017). Al-Syatibi Approach in Fatwa Standardizations and its Effect of States' Fatwa Committee. International Journal of Academic Research in Business and Social Sciences, 7(4), 1175-1183.

Asni, F. A. H. M. (2017). The Practices Of Weak (Daif) Hadiths In Production Of Islamic Law From The Perspectives Of Hadith Studies And Fatwa Legislators In Malaysia. Al-Qanatir: International Journal of Islamic Studies, 7(1), 1-9.

Asni, F. A. H. M., Sulong, J., \& Ismail, A. (2017). Penggunaan hadis daif dalam fatwa mengenai wasiat di Malaysia serta langkah penyelesaiannya. Journal of Hadith Studies, 2(1): 3950.

Asni, F., \& Sulong, J. (2021). The mura'ah al-khilaf and ma'alat method in fatwa decisions: its application for fatwa coordination related to conditional hibah in Malaysia. International Journal of Islamic and Middle Eastern Finance and Management.

Asni, F., Mahamud, M. A., \& Sulong, J. (2020). Socio-economics and management of Muslim cemetery waqf using istibdal and GIS method in Penang state. Journal of Islamic Accounting and Business Research.

Asni, M. F. A. H. M., \& Sulong, J. (2016). Fatwa berhubung wasiat wajibah dan keseragaman peruntukannya dalam fatwa Negeri-Negeri Di Malaysia. Al-Qanatir International Journal of Islamic Studies, 5(1), 1-15.

Asni, M. F. A. H. M., \& Sulong, J. (2017). Fatwa Coordination between States: Analysis Of The Practices Of Standardization And Its Method In Malaysia. Journal of Fatwa Management and Research, 9(1), 86-109.

Asni, M. F. A. H. M., \& Sulong, J. (2017). Penyelarasan Fatwa Antara Negeri-Negeri: Analisis Amalan dan Kaedah Penyeragamannya di Malaysia. Nilai: Universiti Sains Islam Malaysia.

Asni, M. F. A. H. M., \& Sulong, J. (2017). Penyeragaman Fatwa Berhubung Isu-Isu Wakaf di Malaysia: Satu Sorotan Awal: Standardisation of Fatwa Regarding Waqf Issues in Malaysia: A Literature Review. Journal of Fatwa Management and Research, 9(1), 110128.

Astro Awani. (2019). Kedah antara negeri tertinggi tolak vaksin. See: https://www.astroawani.com/berita-malaysia/kedah-antara-negeri-tertinggi-tolakvaksin-199898 (Accessed on 30.8.2021).

Berita Harian. (2016). Berdosa dedah anak bahaya penyakit tanpa vaksin : Mufti. See: https://www.bharian.com.my/node/147522 (Accessed on 30.8.2021). 
Berita Harian. (2016). Wajib ambil vaksin: Mufti. See: http://www.utusan.com.my/berita/nasional/wajib-ambil-vaksin-8211-mufti 1.347847(Accessed on 30.8.2021).

Berita Harian. (2021). TMJ mahu jumpa 779 guru tolak divaksin. See: https://www.bharian.com.my/berita/nasional/2021/08/854518/tmj-mahu-jumpa779-guru-tolak-divaksin (Accessed on 30.8.2021).

Bernama. (2016). Vaksin Halal: Rakyat Diminta Tidak Ragu-ragu Ambil Suntikan Imunisasi. See: http://plus.bernama.com/v1/news2.php?id=916117\&wc= (Accessed on 30.8.2021).

Bharian. (2020). Agenda tangani COVID-19 jamin kesejahteraan, kesihatan rakyat. See: https://www.bharian.com.my/berita/nasional/2020/10/743637/agenda-tanganicovid-19-jamin-kesejahteraan-kesihatan-rakyat (Accessed on 30.8.2021).

Bharian. (2021). Varian Delta boleh merebak 15 saat. See: https://www.bharian.com.my/berita/nasional/2021/07/839796/varian-delta-bolehmerebak-15-saat (Accessed on 30.8.2021).

Bhukhari, A. M., \& Subri, I. M. (2020). Mendepani Cabaran Pandemik Covid-19 Di Malaysia: Aplikasi Konsep Murunah Dalam Fiqh Ibadah. Perdana: International Journal of Academic Research, 9(1), 11-23.

Buang, A. H., \& Che Rosli, C. R. (2017). Persepsi dan Penerimaan Mahasiswa Terhadap Fatwa Negeri Selangor. Journal of Fatwa Management and Research, 9(1), 129-147. https://doi.org/10.33102/jfatwa.vol9no1.44

CNN Indonesia. (2021). MUI: Tes Swab Covid Tidak Membatalkan Puasa. See: https://www.cnnindonesia.com/nasional/20210408093949-20-627308/mui-tes-swabcovid-tidak-membatalkan-puasa (Accessed on 30.8.2021).

COVID-19/Kementerian Kesihatan Malaysia. (2021). Terkini Harian. Lihat: https://covid19.moh.gov.my/ (Accessed on 30.8.2021).

Dahlan, M. A., Abdul Hamid, S., \& Abdul Rahman, N. N. (2014). Sejarah penginstitusian fatwa di negeri Perlis: Pentadbiran dan metodologi penetapan. In: 23rd International Conference of Historians of Asia 2014 (IAHA2014), 23 - 27 August 2014, Alor Setar, Kedah, Malaysia.

Dar al-Ifta' al-Misriyyah. (2003). Ra'yu al-Syara`fi al-Tat`im Dhidd Syilal al-Atfal. Dar al-Ifta’ alMisriyyah. Siri. 632

Federal Territory Mufti Department. (2021). THE RULING OF DOING SWAB TEST WHILST FASTING. $\quad$ https://muftiwp.gov.my/en/artikel/irsyad-fatwa/irsyad-fatwa-khasramadhan-cat/4749-irsyad-fatwa-ramadhan-edition-series-177-the-ruling-of-doingswab-test-whilst-fasting(Accessed on 30.8.2021).

Ibn 'Abidin, M. A. (2001). Raddu Al-Mukhtar 'Ala Al-Durri Al-Mukhtar. Beirut: Dar al-Fikr Ibn al-Uthaimin, M. S. (1999). Majmu' Fatawa Wa Rasail Ibn Uthaimin. Riyad: Dar al-Qasim li al-Nashr.

Ibn Bazz, A. A. (1999). Majmu' Fatawa Ibn Bazz. Riyad: Dar al-Qasim li al-Nashr.

Ishak, M. S. I., \& Asni, F. (2020). The role of maqasid al-Shari'ah in applying figh muamalat into modern Islamic banking in Malaysia. Journal of Islamic Accounting and Business Research.

Ismail, A. M. (2020). Fatwa Sebagai Mekanisme Pencegahan Penularan Pandemik Covid-19: Fatwa as Preventive Mechanism of Containing the Spread of Covid-19 Pandemic. Journal of Fatwa Management and Research, 14-25. 
Ismaweb. (2021). Rujuk mufti jika ada persoalan mengenai hukum hakam keraguan. See: https://ismaweb.net/2021/02/04/rujuk-mufti-jika-ada-persoalan-mengenai-hukumhakam-keraguan/ (Accessed on 30.8.2021).

Khudzri, W. A. R. (2006). Analisis Penggunaan Kaedah Istinbat Dalam Penetapan Fatwa Di Malaysia: Kajian Di Jabatan-Jabatan Mufti Terpilih. PhD Dissertation, Department of Islamic Studies, School of Humanities, USM.

Saudi, L. d. (1996).al-Tabib al-munawib lahu tark al-jum'ah. Fatwa al-Lajnah al-Daimah li alBuhuth al-'Ilmiyyah wa al-Ifta'. Riyad: Dar al-'Asimah.

Al-Islami, M. A.. (1990). Hukm ijra' al-'uqud bi alat al-ittisal al-hadithah. See: https://www.iifaaifi.org/en/7583.html (Accessed on 30.8.2021).

Al-Islami, M. A. (2013). Bayan al-Tsani min Majma` al-Fiqh al-Islami al-Duwali bi Sya'n Wujub al-Tat 'im Dhidd Syilal al-Atfal. See: http://www.iifa-aifi.org/2683.html (Accessed on 30.8.2021).

Al-Islami, M. A. (2021). COVID-19 VACCINES DURING THE FAST OF RAMADAN. See: https://www.iifa-aifi.org/en/12112.html (Accessed on 30.8.2021).

Minister in the Prime Minister's Department of Religious Affairs. (2020). Al-Bayan. Putrajaya: Pejabat Menteri di Jabatan Perdana Menteri Hal Ehwal Agama.

Muslim, H. (2006). Sahih Muslim. Riyad: Dar al-Taibah.

Muzakarah National Fatwa Committee. (2013). Fatwa Munakahat. Putrajaya: JAKIM

Nawi, A. M., \& Hamzah, M. I. (2014). Mobile Fatwa (M-Fatwa): The Integration Of Islamic Fatwa Through Mobile Technology. Turkish Online Journal of Distance Education, 15(2), 108-116.

Omar, S. N. A. C., \& Hussin, M. N. M. (2018). Pemakaian Kaedah-Kaedah Fekah Dalam Institusi Fatwa Di Wilayah Persekutuan Dari Tahun 2010-2014. Online Journal of Research in Islamic Studies, 5(3), 37-64.

Perlis State Mufti Department. (2021). Himpunan Fatwa Negeri Perlis. See: https://muftiperlis.gov.my/index.php/himpunan-fatwa-negeri (Accessed on 30.8.2021).

Perlis State Mufti Department. (2021). Irsyad Hukum. See: https://muftiperlis.gov.my/index.php/bahagian-fatwa/panduan-hukum (Accessed on 30.8.2021).

Perlis State Mufti Department. (2021). Irsyad Hukum. See: https://muftiwp.gov.my/artikel/bayan-linnas/3129-bayan-linnas-siri-ke-166kewajiban-mengambil-vaksin-mengikut-jadual-imunisasi-kebangsaan-daripadaperspektif-islam (Accessed on 30.8.2021).

Rosidi, M. H. (2021). Penerimaan Fatwa Dalam Kalangan Masyarakat Muslim Malaysia: Satu Tinjauan Literatur: Acceptance of Fatwa Among Malaysian Muslim Society: A Literature Review. Journal of Fatwa Management and Research, 24(1), 45-62.

Sanu, M. Q. (2000). Adawat al-Nazar al-ljtihadi al-Manshud. Beirut: Dar al-Fikr.

Selangor State Mufti Department. (2016). Hukum akad nikah menerusi siding video video conference. See: https://www.muftiselangor.gov.my/fatwa-personalisation/fatwatahunan/keputusan-fatwa-xwarta/2016/660-hukum-akad-nikah-menerusi-sidangvideo-video-conference (Accessed on 30.8.2021).

Selangor State Mufti Department. (2021). Semakan Semula Pandangan Hukum dan Kaedah Pengurusan Jenazah Orang Islam Covid-19. See: https://www.muftiselangor.gov.my/senarai-pengumuman/1071-taudhih-al-ahkam- 
semakan-semula-pandangan-hukum-dan-kaedah-pengurusan-jenazah-orang-islamcovid-19 (Accessed on 30.8.2021).

Harian, S. (2020). Golongan antivaksin tolak vaksin Covid-19. See: https://www.sinarharian.com.my/article/112438/KHAS/Covid-19/Golonganantivaksin-tolak-vaksin-Covid-19 (Accessed on 30.8.2021).

Union of African Muslim Scholars. (2006). Mafhum al-Tat`im wa Ahammiyyatihi. See: http://africanulama.org/blog/2016/03/03/343/ (Accessed on 30.8.2021).

Utusan. (2020). COVID-19: Malaysia hadapi bencana luar biasa. See: https://www.utusanborneo.com.my/2020/04/24/covid-19-malaysia-hadapi-bencanaluar-biasa (Accessed on 30.8.2021).

Utusan. (2021). Budayakan norma baharu demi kesejahteraan bersama. See: https://www.utusanborneo.com.my/2020/09/05/budayakan-norma-baharu-demikesejahteraan-bersama (Accessed on 30.8.2021).

WHO. (2020). Coronavirus disease (COVID-19) Pandemic. See: https://www.who.int/emergencies/diseases/novel-coronavirus-2019 (Accessed on 30.8.2021).

Worldmeters. (2021). COVID-19 CORONAVIRUS PANDEMIC. See: https://www.worldometers.info/coronavirus/ (Accessed on 30.8.2021).

Yusli, A. Y., Asni, F., \& Umar, A. I. binti. (2021). The Role of Fiqh Method in Strengthening Fatwa Related to Vaccine Injection for Prevent Covid-19 by Perlis State Mufti Department. International Journal of Academic Research in Business and Social Sciences, 11(8), 1439-1449. 